\title{
Impact of Covid-19 Pandemic on Top Tourist Destinations in the World
}

\author{
Sharmin Sultana ${ }^{1 *}$, Tasnim Islam ${ }^{2}$, Mainul Islam ${ }^{3}$ \\ 1. Senior Lecturer, Dept. of Tourism and Hospitality Management, Daffodil International University, \\ Dhaka, Bangladesh \\ 2. Lecturer, Dept. of Business Administration, Southern University Bangladesh \\ Chittagong, Bangladesh. \\ 3. Undergraduate, Dept. of Tourism and Hospitality Management, Daffodil International University \\ Dhaka, Bangladesh \\ *E-mail of the corresponding author: sharmin.sunny53@gmail.com
}

\begin{abstract}
COVID-19, a variant of novel corona virus, spread all over the world in eight to nine months. Almost all business sector of the world is affected by this global pandemic. Tourism industry is not a single industry, but it is connected with many other industries directly or indirectly. For example, the transportation systems airlines, bus, train, cruise ships and accommodation facilities like hotel, motel, home stay and other tourism service provider like travel agency or tour operator all of these are connected with this industry. Thousands of flights are cancelled, luxurious hotels are empty, no business for tour operator and travel agencies, people involved with tourism industry are losing jobs or not getting salaries fully. The COVID-19 situation has paused all of these sectors' businesses. The purpose of this study is to show the impact of covid-19 in the most popular tourist destinations in the world and provide some recommendations to overcome the crisis. Qualitative in manner, the research paper used secondary method of data from website materials, newspapers, organizational statistics on COVID-19 occurrences all over the popular tourist destinations in the world. This review illustrates a concrete overview about the impact of COVID-19 in popular destinations and provides some recommendations further to overcome it. This paper may guide further research in quantitative method.
\end{abstract}

Keywords: COVID-19, Tourism destinations, Economy, Tourism Industry

DOI: $10.7176 / \mathrm{JTHS} / 50-07$

Publication date:September $30^{\text {th }} 2020$

\section{Introduction}

The novel coronavirus or COVID-19 is the catchword for year 2020. The rapid spread of novel coronavirus (2019nCoV), since the first case occurred in December 2019 in Wuhan, Mainland China, led to a significant reduction in almost all global tourism (Estrada et al, 2020). As report by World Health Organization (WHO) the total confirmed cases of COVID-19 worldwide are 17,918,582 confirmed cases of COVID-19, including 686,703 deaths, reported to WHO (3rd August 2020). Since 31 December 2019 and as of 03 August 2020, 18056310 cases ofCOVID-19 (in accordance with the applied case definitions and testing strategies in the affected countries) have been reported, including 689219 deaths.

More than 16.5 million people around the world have been diagnosed with the coronavirus. Some 9.6 million patients have recovered, and more than 655,000 have died, according to data from Johns Hopkins University. (Mayberry et al., Aljazeera, 2020). Retrieved from: https://www.aljazeera.com/news/2020/07/coronavirus-fooddisruption-raises-risk-children-live-updates-200728001541137.html

Most people infected with the COVID-19 virus usually experience mild to moderate respiratory illness and recover without requiring special and very advanced treatment. Older people and those having medical problems like cardiovascular disease, diabetes, chronic respiratory disease and cancer are more likely to develop serious illness. The best way to prevent and slow down transmission is to have proper knowledge about the COVID-19 virus, causes and its transmission. One of the best practices to stay safe from infection is by washing hands or using an alcohol-based rub (sanitizer) frequently without touching the face. (Mitra, Chaudhuri et al. 2020)

All the sectors throughout the world are affected by this. People cancelled day trips, holidays, foreign trips; cancelled multiple flights and hotels bookings; postponed cultural events, educational events, sports, family events etc. 
International, regional and local travel restrictions immediately affected national economies, including tourism systems, i.e. international travel, domestic tourism, day visits and segments as diverse as air transport, cruises, public transport, accommodation, cafes and restaurants, conventions, festivals, meetings, or sports events. With international air travel rapidly slows as a result of the crisis, and many countries imposing travel bans, closing borders, or introducing quarantine periods, international and domestic tourism declined precipitously over a period of weeks. Countries scrambled to return travelers home, which in the case of important outbound markets involved hundreds of thousands of citizens in all parts of the world. (Gossling and Scott, 2020)

Corona virus spreads due to personal touch and closeness by people. If anyone touches anything contains that virus and touches his face, eyes, nose or mouth, he/she may be affected by COVID-19. Besides, the virus also spreads by coughing and sneezing. Government imposed lockdown to limit the spreaders of the virus and restricted to stay at home. In many organizations, people are doing "work from home". People are maintaining social distancing whenever they visit markets, offices, hospitals and banks. Whereas, other sectors are trying to recover the damages and losses by managing or delivering all the services through online, tourist destinations are still closed. Only in this industry, people need to travel all around to visit a destination. A destination cannot be transferred to a tourist. It's been five-six months of distribution of corona virus affected areas and number of people all over the world. In many countries the rate is decreasing and government decides to open everything gradually. But now nothing will be same like before. People need to maintain minimum precautions like wearing masks while travelling or moving around, washing hands or using sanitizer frequently.

\section{Literature review \\ 2.1 Pandemic and Tourism}

It is essential to distinguish between a unique pandemic like COVID-19, which is likely to continue into the foreseeable future, and other earth-shattering events - such as world wars, 9/11, SARS (2002-2003), MERS (from 2012), and the Global Financial Crisis (GFC) (2007-2009) - in their long-lasting effects on the international community and on the physical, economic, and financial environments. (Chang, MacAleer and et al., 2020).

The world has experienced a number of major epidemics/pandemics in the last 40 years, yet none had similar implications for the global economy as the COVID-19 pandemic. COVID-19 is not as contagious as measles and not as likely to kill an infected person as Ebola, but people can start shedding the virus several days in advance of symptoms (Bai et al., 2020; Rothe et al., 2020). As a result, asymptomatic people transmit COVID-19 before they know to self-isolate or take other measure like physical distancing in public or wearing mouth/nose coverings to prevent spread of the virus through speaking, coughing, or sneezing. With very limited testing in many countries, also due to the unavailability of tests, unknowingly asymptomatic transmission is thought to be substantive (Li et al., 2020).

None of them led to a longer-term decline in the global development of tourism, and some of them are not even notable, with only SARS $(-0.4 \%)$ and the global economic crisis $(-4.0 \%)$ leading to declines in international arrivals (World Bank 2020a, 2020b). This would suggest that tourism as a system has been resilient to external shocks. (Gossling and Scott, 2020)

The relationships between pandemics and travel are central to understanding health security and global change (Burkle, 2006).In cases of pandemics, tourists cancel their travels avoiding suspect places and people (Nicholl, 2006). Such kinds of pandemics affect directly industries such as tourism and retail service sector (Lee $\&$ McKibbin, 2004). The economic consequences of this outbreak will be serious and they will cause damages not only to the tourist destinations with an important concentration of cases but also at a global level. A similar case is the outbreak of SARS in 2002 (Chou et al, 2003; Siu \& Wong, 2003; Wen, 2003).

Reports on lay-offs and bankruptcies followed, with British airline Fly. Be succumbing first to market pressure, declaring bankruptcy on 5 March 2020 (Business Insider, 2020). Major airlines including Scandinavian Airlines (17 March 2020), Singapore Airlines (27 March 2020) and Virgin (30 March 2020), as well as tour operators including German TUI (27 March 2020) have already requested tens of billions of US\$ in state aid. (Gossling and Scott, 2020)

Hoque, Shikha et al. (2020); Dinarto, Wanto et al. (2020) and Deb and Nafi (2020) researched on the impact of Covid-19 in China, Indonesia and Bangladesh consecutively. Chang, McAleer et.al (2020) and Mitra and Choudhuri (2020) identified on the sustainability issue related to covid-19 impact on the environment consecutively. Gossling, Scott and et al. (2020); Chinazzi, Davis et al. (2020); Folinas and Metaxes (2020); Bakar and Rosbi (2020) researched on the impact of covid-19 outbreak on economy, tourism industry and global changes. 


\section{Objectives of the study}

The purpose of the study is to show the impact of covid-19 in the most popular tourist destinations in the world and provide some recommendations to overcome the crisis.

\section{Research Methodology}

The research is based on secondary data and qualitative in nature. The study is followed by several articles, newspapers, and data from World Economic Forum, World Tourism Organizations and World Health Organization. Further research is possible with quantitative data using statistical tools.

\section{Discussions}

\subsection{Global scenario in Tourist Destination countries}

Most vulnerable covid-19 countries impact on tourism.

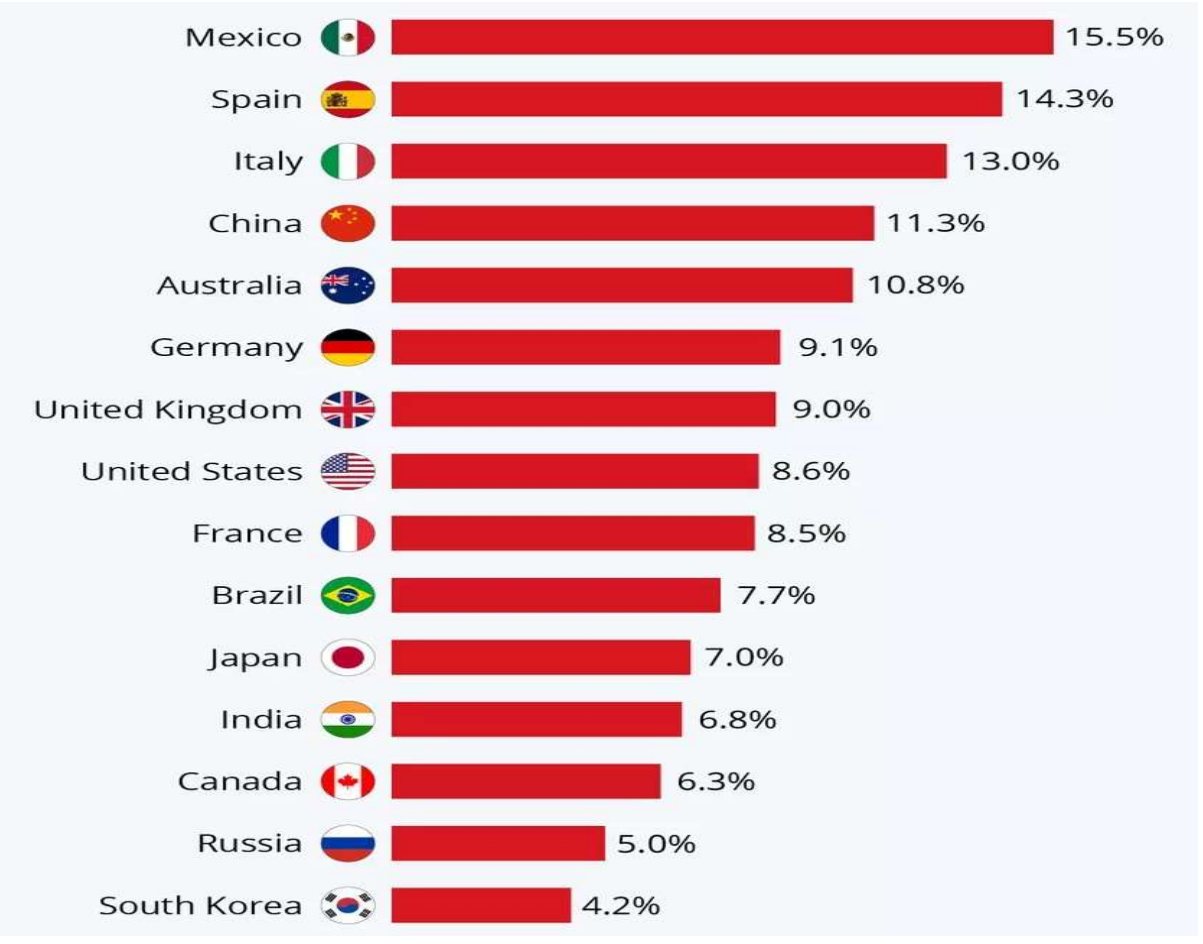

Figure: 1 Most vulnerable covid-19 countries impact on tourism Source: World Travel and Tourism Council (WTTC)

As if the deadly impact of COVID-19 weren't enough, Italy and Spain are also among the countries most vulnerable to the economic fallout of the pandemic. Both countries rely heavily on travel and tourism, which has come to a screeching halt in the past months and remains very limited to this day despite gradual reopening. Moreover, both countries have struggled economically even before the outbreak, with high levels of public debt and unemployment rates among the highest of all OECD countries.

From the chart, based on data from the World Travel \& Tourism Council (WTTC), shows, travel and tourism contributed 14.3 and 13.0 percent, respectively, to Spain's and Italy's GDP last year, including direct contributions from hotels, travel agents, airlines, restaurants and others as well as ripple effects from the billions of dollars, or euros for that matter, that tourists bring to their shores. In the United States for example, the total impact of travel and tourism was considerably smaller at 8.6 percent of GDP. Even at that lower rate, travel and tourism directly support more than 6 million jobs in the United States, with the total contribution to employment amounting to 16.8 million jobs in the U.S. according to WTTC.

According to the World Tourism Organization (UNWTO) the international tourist arrivals will be down by $20 \%$ to $30 \%$ in 2020 when compared with 2019 figures, equivalent to a loss of 300 to 450 US\$ billion in international tourism receipts (exports) - almost one third of the US\$ 1.5 trillion generated globally. The direct contribution of 
the travel and tourism industry accounts today for $3.3 \%$ of the total global GDP and $4.4 \%$ in OECD countries (average) with picks of $14 \%, 13 \%$ and $18 \%$ for countries like Spain, Italy and Greece respectively. Some countries are predicted to face more substantial blows than others due to their high reliance on the sector especially when considering an interesting comparison: out of the top 10 destinations by international tourists arrivals (France, Spain, United States, China, Italy, Turkey, Mexico, Germany, UK and Thailand), 8 result to be the hardest hit by COVID-19, implying that the economic shock on tourism will be further exacerbated in these countries.According to the latest estimates, Asia will see the highest overall drop in travel and tourism revenue in 2020, with China accounting for the lion's share of lost revenue. In Europe, where the tourism industry employs around 13 million people, around $€ 1$ billion in revenues per month is expected to be lost as a result of coronavirus, with Italy and Spain as countries most affected. Italy is likely to close the year with $60 \%$ less presences compared to 2019 , levels equivalent to those registered in the 1960s, when the world was divided in blocks and air travels was a luxury for a few. The Spanish tourism sector would experience losses of around $€ 55$ billion by 2020 with Catalonia expected to be the region most affected registering a loss in tourism turnover of almost $€ 11$ billion.A recent study from the African Unionestimates that the tourism and travel sector in Africa could lose at least $\$ 50$ billion due to the pandemic outbreak and at least 2 million direct and indirect jobs, with devastating effects for tourism spots like Seychelles, Cape Verde, Mauritius and The Gambia will shrink at least 7\%.(Paola Maniga, 2020) Retrieved from: https://www.policycenter.ma/opinion/impact-covid-19-tourism\#.XyhWHygzbIU

\subsection{Tourism Labor Market}

The World Travel and Tourism Council (WTTC) forecast that up to 75 million jobs are at risk in this sector. In fact, a far higher share of low-skilled immigrants, women and students are employed in tourism compared to the total non-financial business economy. (Paola Maniga, 2020)

Retrieved from: https://www.policycenter.ma/opinion/impact-covid-19-tourism\#.XyhWHygzbIU

\subsection{Tourist Arrivals in popular destinations in the world}

\begin{tabular}{|lcr|}
\hline Country & $\begin{array}{r}\text { Most Recent Year } \\
\text { France }\end{array}$ & $\begin{array}{r}\text { Most Recent Value } \\
\text { (Thousands) }\end{array}$ \\
\hline Spain & 2018 & $89,322.00$ \\
\hline United States & 2018 & $82,773.00$ \\
\hline China & 2018 & $79,745.92$ \\
\hline Italy & 2018 & $62,900.00$ \\
\hline Turkey & 2018 & $61,567.20$ \\
\hline United Kingdom & 2018 & $45,768.00$ \\
\hline Mexico & 2018 & $36,316.00$ \\
\hline Germany & 2018 & $31,313.00$ \\
\hline
\end{tabular}

Figure 2: Tourist Arrival 2018

World Tourism Organization via the World Bank 
France is the world's number one destination for international tourists, the most recent figures from the UNWTO show. Almost 90 million people visited the country in 2018.Spain isn't far behind, with over 82 million visitors. The United States, China and Italy complete the top five.These countries are also among the hardest-hit by COVID-19, with the US, Italy, France and Spain (along with the United Kingdom and Brazil) to date recording the world's highest number of confirmed coronavirus deaths.Lockdowns caused havoc in these economies - as they have in many others around the globe - and countries reliant on travel and tourism have seen "particularly large" disruptions, according to the International Monetary Fund.Of the top five most visited nations, Spain in particular will be feeling the heat in this respect - international tourists spend about $\$ 81$ billion in the country annually. That's over $16 \%$ of its total exports, while the same figure is under $10 \%$ for France and Italy. Those numbers pale in comparison to Saint Lucia, though, where international tourism receipts make up more than $81 \%$ of total exports. Globally, the tourism industry accounts for $10 \%$ of GDP and jobs.

\subsection{Effects of COVID-19 pandemic on hospitality industry}

According to American Hotel \& Lodging Association (AHLA),

\subsubsection{Historic Low Occupancy}

- Impact to travel industry 9x worse than 9/11. (Tourism Economics)

- Nearly 50\% revenue decline in 2020, \$124B lost off \$270B total (Oxford Economics)

- $\quad$ Eight in 10 hotel rooms are empty. (STR)

- 2020 is projected to be the worst year on record for hotel occupancy. (CBRE)

- Forecasted occupancy rate for 2020 worse than 1933 during Great Depression. (CBRE)

\subsubsection{Staggering Job Loss}

- $\quad 70 \%$ of hotel employees have been laid off or furloughed. (Oxford Economics and Hotel Effectiveness)

- Nearly 1.6 million hotel employees out of work and

- $\$ 2.4$ billion in weekly lost wages due to the crisis (Oxford Economics and Hotel Effectiveness) Nearly 3.9 million total hotel-supported jobs have been lost since the crisis began (Oxford Economics)

\subsection{Post Covid-19 Scenario of Top Tourists Destinations 5.5.1 Italy}

Italy has found itself at the epicenter of the second-largest coronavirus (COVID-19) outbreak after China. As the fifth most popular tourist destination worldwide, Italy was expected to receive 65 million arrivals in 2020 and see 65 million domestic trips on top of that. However, facing a pandemic, the Italian Government has placed the whole country in lockdown until 3 April, after initially starting with the north, including the Veneto and Lombardy regions, home to Venice and Milan, respectively, where the virus outbreak has been most intense.In 2019, 98 million visitors were recorded at culture, heritage and museum sites, while the activities and experiences including shopping by international visitors was worth USD14 billion to the local economy.

According to Euromonitor International's Travel Forecast Model, the impact of an extreme epidemic on inbound arrivals could lead to a drop of $11.2 \%$ from the baseline forecast for 2020 , leading to a decline of eight million arrivals and USD5.7 billion receipts, with an expected recovery time of three years. Many of Italy's 32,965 hotels are lying empty, with many experiencing zero \% occupancy. According to Euromonitor International's Travel Forecast Model, the impact of an extreme epidemic on inbound arrivals could lead to a decline of eight million arrivals to Italy compared to the baseline. (Breamner 2020, Euromonitor International). Retrieved from:https://blog.euromonitor.com/italy-in-crisis-as-tourism-demand-collapses-amid-coronavirus-pandemic/

Coronavirus-infected in at least 27 countries could be traced the origins to either Italy or Italians. The countries Austria, Bosnia and Herzegovina, South Africa, Greece, Russia, the Netherlands, neighbor Switzerland, Portugal, Czech Republic, Ireland, Argentina, Ukraine, Iceland, Morocco, Latvia, Jordan, Tunisia, Andorra, Luxembourg, Mexico, Dominican Republic, Lithuania, Nigeria, Denmark, North Macedonia, Romania, and Brazil.The high number of coronavirus infection cases in Italy may be explained by the expanding air travel with China. Italy is 
the European nation with the highest number of air connections with China after the air connections between the two countries tripled earlier this year. Italy signed a memorandum of understanding (MoU) with China in early January 2020 to expand the air links between the two countries in order to expand tourism. The weekly passenger flights to China were announced to be increased by 108, and by a further 56 through 2021 and 2022.(Duddu, 2020)Retrieved from: https:/www.pharmaceutical-technology.com/features/covid-19-italy-coronavirus-deathsmeasures-airports-tourism/

\subsubsection{Spain}

Spain was hit hard. Latest figures released on Friday show the country had confirmed 272,421 cases and 28,432 deaths. Nationally, Spain only includes deaths of people who tested positive for the virus.By including regional figures of those suspected to have Covid-19, El Pais calculated a total of 44,868 deaths. This would mean Spain has the second-highest death toll in Europe, just behind the UK, which has recorded 45,837 deaths. (BBC, 2020) Retrieved from: https:/www.bbc.com/news/world-europe-53551863

The sector has recorded its worst semester ever, with a 97\% drop in visitors and 750,000 jobs at risk. Spain's tourism industry continues to feel the impact of the coronavirus crisis. According toNational Statistics Institute (INE), just 204,926 international visitors arrived in Spain in June, a drop of 97.7\% from the same month in 2019. This culminates the worst semester on record for the Spanish tourism industry, with just 10.78 million visitors, a fall of $71.7 \%$ from the same period in 2019 . Tourist spending in the first half of the year has also plummeted $70.6 \%$ to just $€ 11.84$ billion. This means that the sector has lost 27.3 million visitors and $€ 28.4$ billion in revenue in the first half of the year compared with the same period last year.The tourism sector has been one of the hardest-hit by the coronavirus pandemic and the resulting global restrictions on travel. In mid-March, the Spanish government declared a state of alarm in a bid to curb the spread of Covid-19, which limited all non-essential trips to the country. That month, international visitors fell by two thirds. The situation worsened in April and March, with zero tourist arrivals recorded - a previously unthinkable figure in a country where tourism accounts for $11.9 \%$ of gross domestic product (GDP).

(Retrieved from: https://english.elpais.com/economy_and_business/2020-08-05/covid-19-crisis-devastatesspains-tourism-industry.html)

\subsubsection{France}

France is one of the most visited countries in the world, and tourism accounts for nearly $8 \%$ of its GDP. France is one of the most visited countries in the world. According to the country's Ministry for Europe and Foreign Affairs, 89.4 million visitors toured France in 2018 and tourism accounts for nearly $8 \%$ of its gross domestic product.It also welcomes around 2.7 million Chinese tourists each year, Le Maire said. "It won't be the same, of course, in 2020." (CNBC; Abigail 2020).

Retrieved from: https://www.cnbc.com/2020/02/23/coronavirus-impact-france-sees-tourism-numbers-fall-by30percent-to-40percent.html

The French government's undertaking followed a UN announcement that the coronavirus crisis has cost the global tourism sector 273 billion euros in lost revenue during the first five months of 2020. International tourist arrivals fell by 300 million - or 56 percent - in that period as lockdown restrictions to control the spread of Covid-19 came into effect. International tourism arrivals rose by four percent in 2019 to 1.5 billion, with France the world's most visited country, followed by Spain and the United States. (rfi news, 2020).

Retrieved from: https:/www.rfi.fr/en/france/20200729-france-boosts-support-for-tourism-as-covid-eats-320bnout-of-global-sector-economy-coronavirus

\subsubsection{Thailand}

The first novel corona virus (nCoV) infection in Thailand was reported on 13 January 2020, making it the first country outside China to report such infection. The Tourism Authority of Thailand (TAT) announced on Monday that tourist arrivals plummeted by $44.3 \%$ in February, the Bangkok Post reports. TAT Governor Yuthasak Supasorn said that the country is bracing for millions fewer foreign tourists in 2020 compared to 2019, anticipating a drop to 30 million from last year's 39.8 million. (Retrieved from: https://www.businessinsider.com/tourism-inthailand-plummets-amidst-coronavirus-outbreak-2020-3) 
Industries that are expected to be hit by the coronavirus outbreak in Thailand are tourism, aviation, shipping, and hospitality (including hotels and restaurants). Thailand is estimated to lose $\$ 1.15 \mathrm{bn}$ in revenues from tourism in Q1 2020 due to fall in Chinese air travellers alone, according to estimates by International Civil Aviation Organization (ICAO). The impact could be deeper considering a steep fall in visitors from rest of the world.(Retrieved from: https://www.pharmaceutical-technology.com/features/coronavirus-affected-countries-thailand-measures-impacttourism/)

The 'Covid-19 and Tourism' report released by the United Nations Conference on Trade and Development (UNCTAD) is based on three scenarios for the industry, with lockdown measures lasting 4 months, 8 months and 12 months.In those scenarios, revenues would fall $\$ 1.17$ trillion, $\$ 2.22$ trillion and $\$ 3.3$ trillion respectively or between $1.5-4.2 \%$ of the world's gross domestic product (GDP).In such a scenario, revenues could drop by $\$ 1170$ billion respectively; 2220 billion dollars and 3300 billion dollars. At the level of global gross domestic product (GDP) for tourism, there is a decrease varying between 1.5 and $4.2 \%$ of the total. The study does not specify which of these three scenarios may be the most likely, although UNCTAD experts predict that the middle one would be viewed "as most realistic". (Retrieved from: http://www.asianews.it/news-en/Covid-19-torpedoes-tourism,-47billion-in-lost-revenue-forThailand-50503.html)

Tourism-related businesses such as restaurants, entertainment venues, spas, massage parlours and retailers are expected to furlough an additional 4.75 million employees. Some 95 per cent of those who are being rendered jobless have a monthly income of less than 20,000 baht. Retrieved from: https:/www.ttgasia.com/2020/04/17/unemployment-rates-in-thai-tourism-sector-climbs/

For UN experts, Thailand (like France) is expected to suffer losses of around $\$ 47$ billion. The nation destined to lose the most is the United States with a drop of 187 billion dollars, followed by China with 105 billion (provided that the restrictions last "only" four months, and are not extended). According to the latest estimates, up to 8.4 million people are at risk of losing their job and the tourism and entertainment sectors are among the most affected. The National Department for Economic and Social Development puts the collapse in the number of visitors and internal and foreigners could lead to a drop of at least 2.5 million jobs. A figure equal to $64 \%$ of a total of 3.9 million workers in the tourism industry. (Retrieved from: http://www.asianews.it/news-en/Covid-19-torpedoestourism,-47-billion-in-lost-revenue-forThailand-50503.html)

\subsubsection{Mexico}

Mexico, one of the world's top vacation destinations, is among those reopening their doors. This, despite the country's continuing struggle to contain the coronavirus outbreak. Industry experts predict it could take years for Mexico's tourism to recover. (Aljazeera, 2020). Retrieved from: https://www.aljazeera.com/news/2020/07/mexicos-tourism-industry-could-years-recover-

200716104050341.html Due to the COVID-19 pandemic, total tourism consumption in Mexico could decrease approximately 1.6 trillion Mexican pesos in 2020. According to May 2020 forecasts, domestic tourism spending could fall 1.4 trillion Mexican pesos. In turn, international tourism losses could reach 245 billion Mexican pesos, while the contribution of tourism to Mexico's GDP could fall below five percent in 2020. From 2010 to 2018, the tourism sector accounted for an average of 8.5 percent in Mexico's GDP. (Statista 2020) Retrieved from: https://www.statista.com/statistics/1124221/coronavirus-impact-tourism-sector-mexico/

\subsubsection{Canada}

Canada's tourism industry is bracing for the impact of the novel coronavirus on the number of foreign visitors this summer travel season. As a destination that is deeply, globally connected like Toronto is ... it's natural that we will feel some of the impact of these changes at a global level," said Andrew Weir, an executive vice president with Tourism Toronto. "And that's what we're seeing. Chinese tourists generate about C \$2 billion annually in Canada, but their numbers have dwindled and revenue from their visits is expected to be down by C\$550 million by June, Tourism Minister Melanie Joly told reporters in Montreal. Retrieved from: https://www.reuters.com/article/ushealth-coronavirus-canada-tourism/canadas-tourism-industry-deeply-affected-by-virus-outbreak-ministeridUSKBN20T2RR

\subsubsection{China}

Today, China is Canada's second-largest overseas market, accounting for close to 800,000 arrivals, and its highest spending market with more than $\$ 2,800$ per trip.Retrieved from: https://theconversation.com/the-coronavirus-willhit-the-tourism-and-travel-sector-hard-130872. The illness, now officially labeled COVID-19, has raced across 
the globe, infecting tens of thousands of people and killing more than 2,000, predominantly in China. Countries have closed their borders to Chinese travelers; airlines have slashed flights and limited routes. Points of transit across Asia - train stations, bus depots, airports - have seen traffic plummet, and some are nearly deserted. The Chinese tourism market has seen staggering growth over the past two decades. Travel departures from China, according to the United Nations World Tourism Organization, increased from 4.5 million in 2000 to 150 million in 2018. These travelers have become their own economic force, spending $\$ 277$ billion, and many countries have rushed to embrace them. More than 40,000 hotel bookings on the Indonesian island of Bali have been canceled, according to officials there, and the outbreak could shave up to 0.3 percentage points off the country's GDP growth. Billions of dollars in tourism spending are projected to be lost by Vietnam. Tourists from China are the largest group of visitors to Thailand, but the government expects the annual number of Chinese travelers to fall by at least 2 million. The country's tourism sector has rapidly expanded since the government undertook political and economic reforms in 2011, but in 2018, arrivals from the United States and Europe dropped 50 percent (The Atlantic, 2020). Retrieved from:https://www.theatlantic.com/international/archive/2020/02/economycoronavirus-myanmar-china-tourism/606715/

\subsubsection{Australia}

China is Australia's largest inbound market, with just under $1.5 \mathrm{~m}$ arrivals (for all purposes) for the year to November 2019. The market has shown the strongest cumulative average growth rate of $15 \%$ year on year since 2009. China represents $15.5 \%$ of total short-term visitor arrivals into Australia $(9.44 \mathrm{~m})$. More importantly than just visitor numbers, China represents $\$ 12.3 \mathrm{~b}$ in annual tourism receipts to Australia, representing nearly $33 \%$ of all tourism receipts (as of May 2019). Whilst the months of January and February from China to Australia are noted as stronger inbound months due to Chinese Lunar New Year and the arrival of Chinese students studying in Australia, on average, there are 120k Chinese arrivals into Australia each month. The outbound travel ban imposed on many regions in China by the Chinese Government, coupled with the Australian Governments ban on arrivals from China and those who have travelled through China, has resulted in a total loss of Chinese visitors over the last 6 weeks into Australia.Most recent Australian National Account - Tourism Satellite Account 2018-198 estimates indicate an increase of $21.5 \mathrm{k}$ tourism sector employees resulting in 666k total tourism jobs (full time, part time, contract and casual) which is higher than the estimated initial rate of tourism sector employment noted above.(Tourism and Transport Forum, 2020) (Retrieved from: https://www.ttf.org.au/wpcontent/uploads/2020/03/Economic-Impact-of-Coronavirus-TTF.pdf.

The tourism industry is looking at losses of $\$ 3$ billion per month nationally from travel restrictions related to the coronavirus as new data reveals the biggest December fall in international visitors to NSW since statistics began in 1991.There were 15,000 fewer people visiting NSW in December 2019 than in the corresponding month in 2018 and in January 2020 travellers declined by 2300, according to Australian Bureau of Statistics data.The top countries for visitors to the state in January 2020 were China $(59,900$ tourists), America $(37,400)$ and New Zealand $(29,100)$ with the largest annual increases from Hong Kong (up 38 per cent) and China (up 7 per cent). China represents about $\$ 12.3$ billion in annual tourism to Australia, almost one-third of all tourism receipts. (The Sydney Morning Herald, 2020). (Retrieved from: https:/www.smh.com.au/national/nsw/tourism-losses-to-hit-3-billion-permonth-as-data-shows-visitor-slump-20200316-p54alm.html)

\section{Recommendations}

\subsection{Opening of Few Tourists Spots}

Some of the tourists' spots can be open up to sustain the tourism and hospitality industry. Due to covid-19 pandemic crisis, many employees lost their jobs in hotels, many airlines are going to be bankrupt and shut down, many investors in hospitality industry have lost their business and capital. So, for sake of them, some the spots may be opened up.

\subsection{Following Health Precautions and Social Distancing}

It's necessary to follow instructions to not get affected by corona virus or spreading it. Some regulations and entry restrictions should be imposed. Such as, limiting the number of tourists at a time at one spot and restricting the duration of opening hours. 


\subsection{Promotional offers and discounts}

Hotels may offer some discounts and complimentary offers such as buy 1 get 1 . But the authority should be sensible to promote these types of offers among tourists.

\section{Conclusion}

Tourism is an industry which gives people happiness, energy and enthusiasm. For last 6 months this industry has to an end almost because of global pandemic. Every countries-imposed lockdown and people's mobility has been restricted. Like other industries this industry was almost at a standstill. Italy, Spain, USA, Mexico, China the top destinations in the world faced huge economic losses in tourism. The financial recovery will take long time. But recently many countries have opened few destinations gradually. They are taking promotional measures. Mostly, they should promote those spots where safety precautions can be availed and offered to everyone both employees and guests. Government, destination management organization, tourists all should be act sensibly so that the tourism industry will sustain besides the covid-19 virus will not spread more.

\section{References}

Abhijit Mitra, Tanmay Ray Chaudhuri, AnkitaMitra, ProsenjitPramanick and Sufia Zaman, "Impact of COVID19 related shutdown on atmospheric carbon dioxide level in the city of Kolkata", Parana Journal of Science and Education. Vol. 6, No. 3, 2020, pp. 84-92.

Ashikul Hoque, Farzana Afrin Shikha, Mohammad Waliul Hasanat, Ishtiaque Arif, Prof. Dr. Abu Bakar Abdul Hamid; "The Effect of Coronavirus (COVID-19) in the Tourism Industry in China", Asian Journal of Multidisciplinary Studies Vol. 3, No. 1, (2020) ISSN 2651-6691 (Print) ISSN 2651-6705 (Online), pp.52-58.

Chia-Lin Chang, Michael McAleer and Vicente Ramos (2020); “A Charter for Sustainable Tourism after COVID-19”, Sustainability; MDPI; http://dx.doi.org/10.3390/su12093671

Deb, Santus Kumar and Nafi, Shohel Md., Impact of COVID-19 Pandemic on Tourism: Perceptions from Bangladesh (June 22, 2020). Available at SSRN: https://ssrn.com/abstract=3632798 or http://dx.doi.org/10.2139/ssrn.3632798

Dinarto, AdriWanto\& Leonard C. Sebastian (2020) “COVID-19: Impact on Bintan's Tourism Sector”; RSIS Commentary, No. 033- 2March 2020

MatteoChinazzi, Jessica T. Davis, Marco Ajelli, CorradoGioannini, Maria Litvinova, Stefano Merler, Ana Pastore y PionttiKunpeng Mu, Luca Rossi, Kaiyuan Sun, Cécile Viboud, XinyueXiong, Hongjie Yu, M. Elizabeth Halloran, Ira M. Longini Jr. and Alessandro Vespignani (2020); "The effect of travel restrictions on the spread of the 2019 novel coronavirus (COVID-19) outbreak"; Science 368 (6489), 395-400; DOI: 10.1126/science.aba9757originally published online March 6, 2020

Nashirah Abu Bakar, SofianRosbi (2020), "Effect of Coronavirus disease (COVID-19) to tourism industry", International Journal of Advanced Engineering Research and Science (IJAERS) [Vol-7, Issue-4, Apr2020] pp.189-193. https://dx.doi.org/10.22161/ijaers.74.23 ISSN: 2349-6495(P) | 2456-1908(O)

Stefan Gössling, Daniel Scott \& C. Michael Hall (2020): Pandemics, tourism and global change: a rapid assessment of COVID-19, Journal of Sustainable Tourism, DOI: 10.1080/09669582.2020.1758708

Sotiris FOLINAS and Theodore METAXAS (2020), "Tourism: The Great Patient of Coronavirus COVID2019”, DOI: 10.13140/RG.2.2.12069.24804

Breamner (2020), Euromonitor International; Retrieved from: https://blog.euromonitor.com/italy-in-crisis-astourism-demand-collapses-amid-coronavirus-pandemic/

Duddu, (2020). Retrieved from: https://www.pharmaceutical-technology.com/features/covid-19-italycoronavirus-deaths-measures-airports-tourism/

BBC, (2020). Retrieved from: https://www.bbc.com/news/world-europe-53551863

https://english.elpais.com/economy_and_business/2020-08-05/covid-19-crisis-devastates-spains-tourismindustry.html

CNBC; Abigail (2020); Retrieved from:https://www.cnbc.com/2020/02/23/coronavirus-impact-france-sees; tourism-numbers-fall-by-30percent-to-40percent.html

rfi news, (2020); Retrieved from: https://www.rfi.fr/en/france/20200729-france-boosts-support-for-tourism-ascovid-eats-320bn-out-of-global-sector-economy-coronavirus

https://www.businessinsider.com/tourism-in-thailand-plummets-amidst-coronavirus-outbreak-2020-3 
https://www.pharmaceutical-technology.com/features/coronavirus-affected-countries-thailand-measures-impacttourism/

http://www.asianews.it/news-en/Covid-19-torpedoes-tourism,-47-billion-in-lost-revenue-forThailand50503.html

https://www.ttgasia.com/2020/04/17/unemployment-rates-in-thai-tourism-sector-climbs/

Aljazeera, (2020); Retrieved from: https:/www.aljazeera.com/news/2020/07/mexicos-tourism-industry-couldyears-recover-200716104050341.html

Statista (2020); Retrieved from: https://www.statista.com/statistics/1124221/coronavirus-impact-tourism-sectormexico/

https://www.reuters.com/article/us-health-coronavirus-canada-tourism/canadas-tourism-industry-deeplyaffected-by-virus-outbreak-minister-idUSKBN20T2RR

https://theconversation.com/the-coronavirus-will-hit-the-tourism-and-travel-sector-hard-130872

https://www.theatlantic.com/international/archive/2020/02/economy-coronavirus-myanmar-chinatourism/606715/

https://www.ttf.org.au/wp-content/uploads/2020/03/Economic-Impact-of-Coronavirus-TTF.pdf

The Sydney Morning Herald, (2020); Retrieved from: https://www.smh.com.au/national/nsw/tourism-losses-tohit-3-billion-per-month-as-data-shows-visitor-slump-20200316-p54alm.html

The Atlantic, (2020); Retrieved from: https://www.theatlantic.com/international/archive/2020/02/economycoronavirus-myanmar-china-tourism/606715/

Tourism and Transport Forum, (2020). Retrieved from: https://www.ttf.org.au/wpcontent/uploads/2020/03/Economic-Impact-of-Coronavirus-TTF.pdf

Mayberry et al. Aljazeera, 2020). Retrieved from:https://www.aljazeera.com/news/2020/07/coronavirus-fooddisruption-raises-risk-children-live-updates-200728001541137.html 